\title{
11- $\beta$ Hydroxysteroid Dehydrogenase Type 2 in Human Adult and Fetal Lung and Its Regulation by Sex Steroids
}

\author{
MARK R. GARBRECHT, JONATHAN M. KLEIN, TROY A. MCCARTHY, THOMAS J. SCHMIDT, \\ ZYGMUNT S. KROZOWSKI, AND JEANNE M. SNYDER
}

\author{
Department of Anatomy and Cell Biology [M.R.G., J.M.S.], Department of Pediatrics [J.M.K., T.A.M., J.M.S], Department of Molecular \\ Physiology and Biophysics [T.J.S], Roy J. and Lucille A. Carver College of Medicine, University of Iowa, Iowa City, \\ Iowa 52242; Baker Heart Research Institute [Z.S.K.], Melbourne, Victoria 8008, Australia
}

\begin{abstract}
HSD2) oxidizes the biologically active glucocorticoid (GC), cortisol, to inactive cortisone. We characterized HSD2 gene expression and activity in human adult and fetal lung tissues and in cultured fetal lung explants, and examined the potential regulation of HSD2 in the fetal lung by sex steroids. Human adult lung, fetal lung, and cultured fetal lung explant tissues contained similar amounts of HSD2 mRNA. However, higher levels of HSD2 protein were detected in human fetal lung tissue than in adult lung, with expression being restricted to a subset of epithelial cells in the fetal lung tissue. Differentiated fetal lung explants maintained in culture expressed higher levels of HSD2 protein and enzymatic activity than undifferentiated fetal lung tissues. Finally, HSD2 protein levels were decreased in male, but not female, fetal lung explants treated with $17-\beta$ estradiol. In contrast, 5- $\alpha$ dihydrotestosterone did not significantly affect HSD2 levels. These data indicate that HSD2 protein and activity levels increase in parallel with the differentiation of alveolar type II epithelial cells in vitro, and that HSD2 protein levels are regulated by $17-\beta$ estradiol in male fetal lung tissue. (Pediatr Res 62: 26-31, 2007)
\end{abstract}

$\mathrm{I}^{\mathrm{n}}$ n humans, the biologically active GC, cortisol, has a hydroxyl group at the $11-\beta$ position of the steroid ring, whereas the biologically inactive GC, cortisone, has a ketone group at this position (1). The interconversion between cortisol and cortisone is catalyzed by the HSD, HSD1 and HSD2 (1). HSD1 is an $11-\beta$ reductase that converts the 11 -keto GC, cortisone, to the 11-hydroxy GC, cortisol (Fig. 1). In contrast, HSD2 is an 11- $\beta$ dehydrogenase that converts cortisol to cortisone (Fig. 1). Thus, the HSD1 and HSD2 enzymes can increase or decrease the local concentrations of biologically active GC in peripheral tissues (1).

Glucocorticoids affect lung fluid transport, cell division, differentiation, pulmonary surfactant production, and inflammation $(2,3)$. Cortisol levels increase in amniotic fluid during pregnancy and a surge in fetal GC levels near term is necessary for fetal lung maturation in preparation for extrauterine life $(2,4)$. Synthetic GCs, such as dexamethasone and prednisone, are used to treat inflammatory lung diseases in children and adults, and to promote lung maturity in fetuses at risk

Received September 21, 2006; accepted March 2, 2007.

Correspondence: Jeanne M. Snyder, Ph.D., Department of Anatomy and Cell Biology,

1-550 Bowen Science Building, Iowa City, IA 52242; e-mail: jeanne-snyder@uiowa.edu

This work was supported by the March of Dimes (grant no. 6-FY01-210 to J.M.K.), the National Institutes of Health (grant no. RO1 HL-50050 to J.M.S.), and an American Heart Association Pre-Doctoral Fellowship (M.R.G.). for preterm delivery $(2,3,5)$. However, prenatal exposure to GC has been associated with immune suppression, hypertension, altered nutrient metabolism, and decreased growth hormone levels $(2,6)$. Additionally, antenatal administration of $\mathrm{GC}$ to prevent or treat neonatal lung disease has been linked to decreased somatic growth, altered immune system reactivity, and an increased risk for developing hypertension and insulin resistance later in life (7).

Sex-specific differences in fetal lung maturation have been observed in several species, including humans, with lung development delayed in males compared with females (8). Androgens, such as 5- $\alpha$ dihydrotestosterone, counteract the maturation-promoting effects of GC in human fetal lung explants, whereas estrogens, such as $17-\beta$ estradiol, accelerate fetal lung maturation $(9,10)$.

The human fetal lung actively oxidizes cortisol to cortisone (indicative of HSD2 activity) and this activity decreases as the fetus approaches term, potentially allowing for an increase in the local concentration of biologically active cortisol in the maturing lung (11). HSD2 mRNA and protein have been detected in human adult and fetal lung tissues, as well as in a number of human lung epithelial cell lines $(12,13)$. In contrast, the oxidoreduction of cortisone to cortisol (suggestive of HSD1 activity) is negligible in intact cultured lung explants and undetectable in human fetal lung in vivo $(11,14,15)$.

Explants of undifferentiated, mid-trimester human fetal lung tissue maintained in culture for 5-7 d contain newly differentiated type II alveolar epithelial cells that produce pulmonary surfactant characteristic of the fetal lung near term (16). This model system provides a unique opportunity to study, in vitro, developmental events that normally take several months to occur in vivo $(16,17)$. In the present study, we compared HSD2 expression in undifferentiated human fetal lung tissue and in cultured human fetal lung explants following type II alveolar epithelial cell differentiation. We also compared HSD2 expression in human adult lung versus human fetal lung tissues, and looked for sex-specific differences in HSD2 expression in human fetal lung. Finally, we evaluated the regulation of HSD2 protein in human fetal lung by the sex steroids, $17-\beta$ estradiol and 5- $\alpha$ dihydrotestosterone.

Abbreviations: GC, glucocorticoid; HSD, 11- $\beta$ hydroxysteroid dehydrogenases 


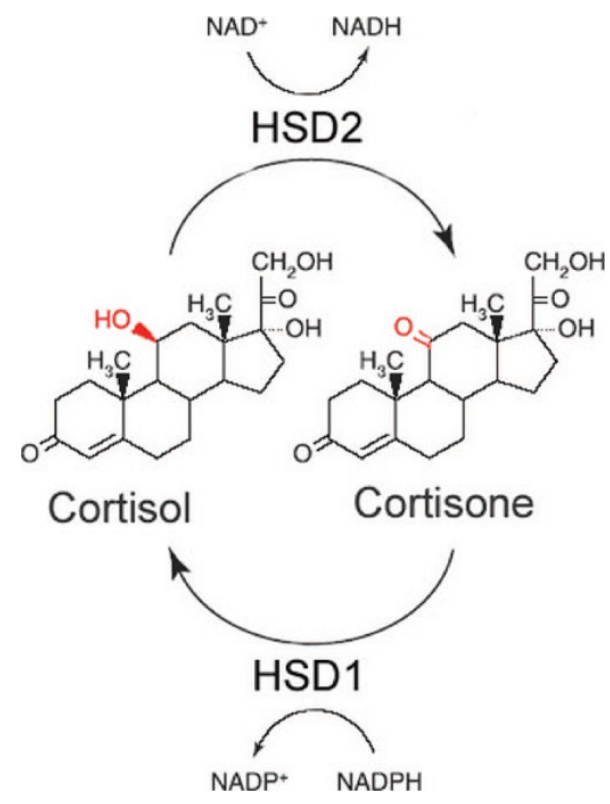

Figure 1. Cortisol metabolism by the $11-\beta$ hydroxysteroid dehydrogenase system. Local concentrations of biologically active GC are increased by HSD1-mediated oxidoreduction of cortisone to biologically active cortisol. HSD2 decreases the local concentration of biologically active GC via the oxidation of cortisol to inactive cortisone.

\section{METHODS}

Human lung tissues. Human adult lung tissues were obtained using a protocol approved by The University of Iowa Human Subjects Review Committee. Adult lung tissues taken from unused donor lungs were obtained from Dr. Michael Welsh, Department of Internal Medicine, University of Iowa. The lungs were maintained in cold isotonic Ringer's solution until processing, which occurred within $24 \mathrm{~h}$ of clamping of donor circulation. Lung tissues were dissected free of major blood vessels and airways, frozen in liquid $\mathrm{N}_{2}$, and stored at $-80^{\circ} \mathrm{C}$.

Human fetal lung explants. Human fetal lung tissues were obtained from mid-trimester abortuses using a protocol approved by The University of Iowa Human Subjects Review Committee. Human fetal lung explants were cultured as described previously, with or without $5-\alpha$ dihydrotestosterone $(500 \mathrm{ng} / \mathrm{mL}=$ $1.7 \mu \mathrm{M})$ or $17-\beta$ estradiol $(500 \mathrm{ng} / \mathrm{mL}=1.8 \mu \mathrm{M})(16)$. The explants were incubated at $37^{\circ} \mathrm{C}$ and media changed daily as previously described (18). Starting tissue (fetal lung tissue before culture) and the harvested cultured explants were frozen in liquid $\mathrm{N}_{2}$ and stored at $-80^{\circ} \mathrm{C}$.

HSD2 enzyme activity assays. Intact control and hormone-treated explants were washed with PBS and then incubated at $37^{\circ} \mathrm{C}$ in $1 \mathrm{~mL}$ of serum-free

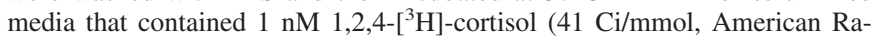
diolabeled Chemicals, St. Louis, MO) for $24 \mathrm{~h}$ on either d 1 (starting tissue) or $\mathrm{d} 6$ (cultured explants). Labeled steroids were then isolated from the media and the production of tritiated cortisone was assessed via thin layer chromatography as previously described (12). HSD2 oxidase activity was determined by calculating the percent conversion of $\left[{ }^{3} \mathrm{H}\right]$-cortisol to $\left[{ }^{3} \mathrm{H}\right]$-cortisone. Parallel assays were performed with no lung tissue to control for spontaneous interconversion between 11-hydroxy and 11-dehydro GC. Upon completion of the assay, the explant tissues were homogenized in $100 \mu \mathrm{L}$ of lysis buffer ( $1 \mathrm{nM}$ phenylmethylsulfonyl fluoride in PBS) and the protein content in the supernatant was determined using Bio-Rad protein assay reagent (Bio-Rad, Hercules, CA). Protein levels were used to control for slight variations in tissue content between experiments. The HSD2 activity was expressed as picomoles of cortisol converted per microgram of protein.

Protein isolation and immunoblot analysis. Lung tissues were homogenized in lysis buffer, centrifuged at $600 \times g$ to pellet debris, and the supernatant collected. Supernatant protein concentrations were quantified as described above. Immunoblotting was performed using a rabbit primary antibody specific for human HSD2 $(2 \mu \mathrm{g} / \mathrm{mL})$ as previously described $(12,19)$. HSD2 protein levels were normalized to $\beta$-actin levels, which were determined on membranes that were stripped and reprobed with a $\beta$-actin MAb (1:7500, Chemicon International, Temecula, CA). Total homogenate proteins from human kidney $(15 \mu \mathrm{g})$ (BioChain, Hayward, CA) were used as a positive control for immunoreactive HSD2 protein.
$R N A$ isolation and semi-quantitative real-time reverse-transcriptase PCR. Lung tissue was homogenized in $1 \mathrm{~mL}$ of TRIzol reagent (Invitrogen, Carlsbad, CA) and total RNA was isolated and quantified as described previously (12). RNA integrity was monitored by examining the ethidium bromide stained $28 \mathrm{~S}$ and $18 \mathrm{~S}$ rRNA bands after electrophoresis on agarose gels. Real-time reverse-transcriptase (RT) PCR was performed in reaction tubes containing $10 \mathrm{ng}$ of total RNA, the Brilliant 1-Step QRT-PCR master mix (Stratagene, La Jolla, CA) and Assays-On-Demand gene expression reagents for either human HSD2 or $\beta$-actin mRNA. Analysis was performed using an Mx3000P QPCR instrument (Stratagene). HSD2 mRNA levels were normalized to those of $\beta$-actin in the same sample.

Immunohistochemistry. Fetal lung tissues were fixed in formalin $(10 \%$ formaldehyde in PBS) overnight and embedded in paraffin. Sections were prepared, mounted on glass slides, and immunostaining performed as previously described using a Vectastain Elite kit (Vector Laboratories, Burlingame, CA) and the HSD2 antibody (200 ng/mL) (18).

Sex determination of human fetal tissues. Total DNA was isolated from fetal lung tissues, resuspended in water, and quantified by determining the absorbance at $260 \mathrm{~nm}$. One microgram of the DNA was used in PCR reactions with primers specific for a homologous region of the $\mathrm{X}$ and $\mathrm{Y}$ chromosomes, as previously described (20).

\section{RESULTS}

HSD2 protein localization in fetal lung tissue and in cultured fetal lung explants. HSD2 protein was present in epithelial cells at the distal tips of prealveolar lung ducts in uncultured human fetal lung tissue (Fig. 2A). HSD2 protein was cytoplasmic and localized to the apical region of the cells (Fig. $2 \mathrm{~B}$ ). HSD2 staining was not observed in more proximal epithelial cells of the lung ducts or in connective tissue. Following $6 \mathrm{~d}$ in explant culture, HSD2 protein was detected in all of the differentiated type II alveolar epithelial cells lining the prealveolar lung ducts (Fig. 2C). Additionally, immunoreactive HSD2 protein was distributed throughout the cytoplasm and nuclei of these epithelial cells (Fig. 2D).

HSD2 gene expression in human adult and fetal lung. Semi-quantitative real-time RT-PCR using total RNA isolated

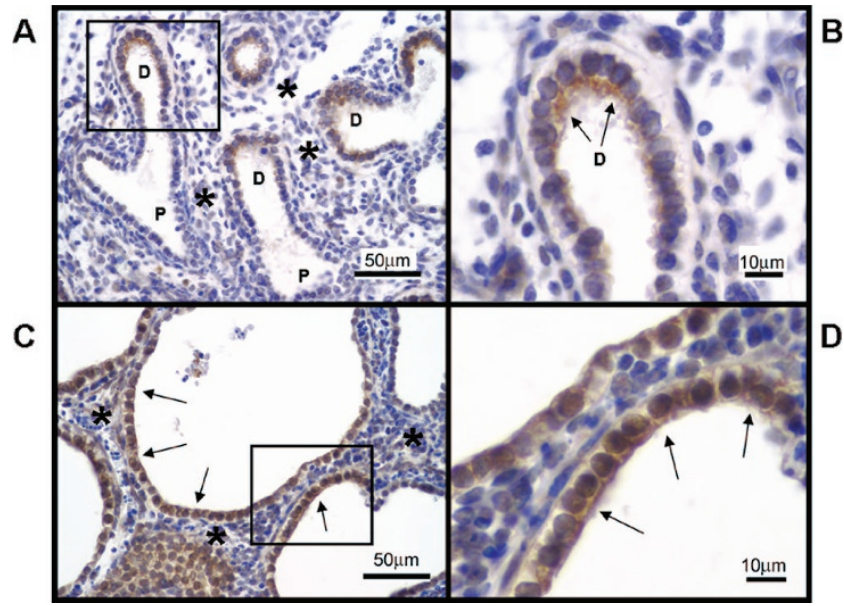

Figure 2. Tissue distribution and subcellular localization of HSD2 protein in human fetal lung tissue. (A) HSD2 protein in the uncultured human fetal lung tissue was localized in epithelial cells at the distal $(D)$ tips of the prealveolar ducts. HSD2 was not present in more proximal $(P)$ epithelial cells of the lung ducts or in the connective tissue (asterisk). (B) Enlargement of boxed area in $A$ illustrating localization of HSD2 to the apical cytoplasm of the epithelial cells. $(C)$ Immunoreactive HSD2 protein was detected in all of the differentiated type II epithelial cells (arrows) in the cultured human fetal lung explants. $(D)$ Enlargement of boxed area in $C$ illustrating the localization of HSD2 protein in the cultured fetal lung epithelial cells. Images in $A$ and $C$ were taken at $40 \times$ magnification. 

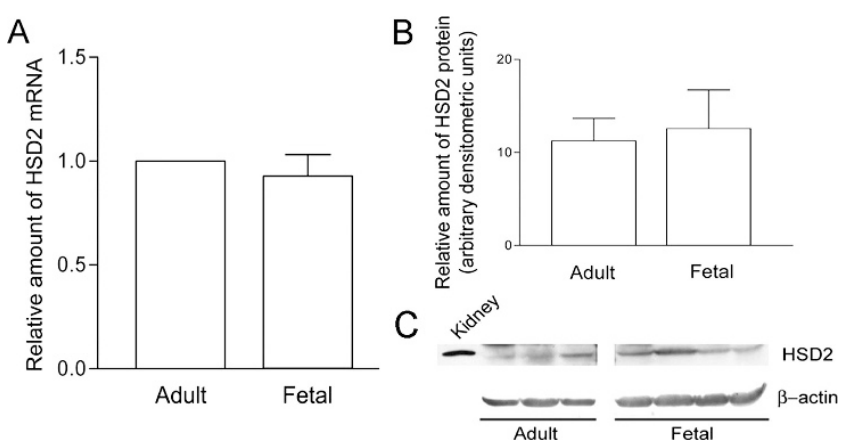

Figure 3. HSD 2 mRNA and protein in human adult and fetal lung tissues. (A) Relative amounts of HSD2 mRNA present in fetal lung $(n=4)$ and in adult lung $(n=4)$, which were normalized to one. $(B)$ The relative amount of HSD2 protein in fetal lung $(n=4)$ and in adult lung $(n=3)$. (C) Representative immunoblots for HSD2 and $\beta$-actin proteins.

from adult $(n=4)$ and fetal lung tissues $(n=4)$ revealed similar levels of HSD2 mRNA (Fig. 3A). Immunoblot analyses for HSD2 protein demonstrated that HSD2 protein levels in human adult $(n=3)$ and fetal lung tissues $(n=4)$ were not significantly different when normalized to those for $\beta$-actin (Fig. 3B).

HSD2 gene expression and activity in starting and cultured fetal lung explants. HSD2 mRNA levels in cultured fetal lung tissues were not significantly different from those in starting fetal lung tissues (Fig. 4A). However, immunoblot analyses revealed significantly higher amounts of HSD2 protein in cultured fetal lung explant tissue compared with levels in uncultured fetal lung tissue (Fig. 4B).
As shown in Figure $4 C(a)$, the cultured fetal lung explants had higher levels of HSD2 oxidase activity than the starting fetal lung tissues. The increase in HSD2 enzyme activity in the cultured fetal lung explants was similar in magnitude to the increase in HSD2 protein observed in the same tissues (Fig. 4, $B$ and $C$ ), although the increase did not reach statistical significance ( $n=4 ; p=0.14$, paired $t$ test). A representative scan showing separation of labeled cortisol and cortisone via thin layer chromatography is shown in Figure $4 C(b)$. Labeled cortisol is the first major peak, while the more polar compound, cortisone, migrates further and is the second peak.

HSD2 protein levels in male versus female fetal lungs and regulation by sex steroids. We performed immunoblot analyses for HSD2 protein on total homogenate proteins from male and female fetal lung tissues. The gender of the fetal lung tissue was determined by PCR (Fig. 5A). The relative amounts of HSD2 protein in male $(n=3)$ and female $(n=5)$ uncultured fetal lung tissues were similar (Fig. 5B). Immunoblot analyses for HSD2 protein were also performed on fetal lung explants that had been cultured in the presence of either $5-\alpha$ dihydrotestosterone (DHT) $(500 \mathrm{ng} / \mathrm{mL})$ or $17-\beta$ estradiol $(500 \mathrm{ng} / \mathrm{mL})$. There was a statistically significant downregulation of HSD2 protein levels in fetal lung explants $(n=11)$ treated with $17-\beta$ estradiol, whereas DHT had no effect (Fig. 6A). When the data were analyzed on the basis of sex ( $n=5$, males and $n=6$, females), there was a significant down-regulation of HSD2 protein levels in male, but not female, fetal lung explants treated with $17-\beta$ estradiol (Fig. 6B). DHT did not have a significant effect on

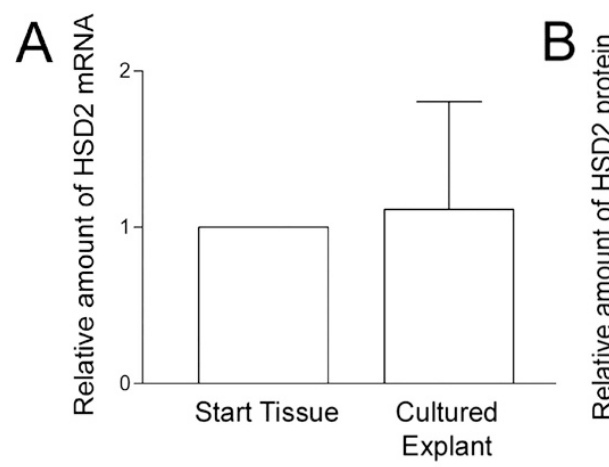

C a)

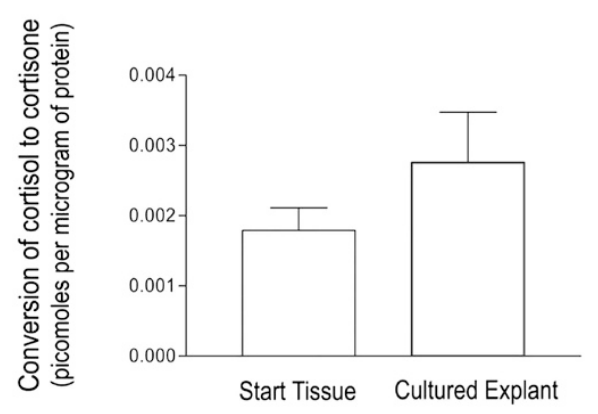

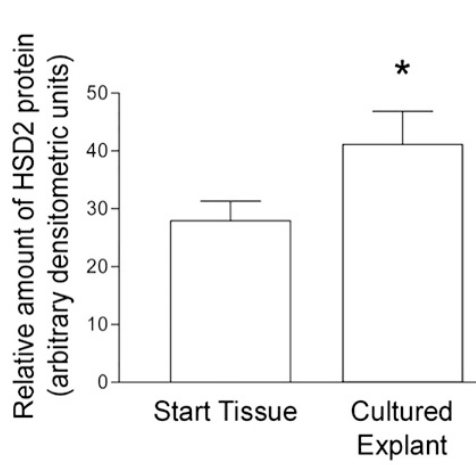

b)

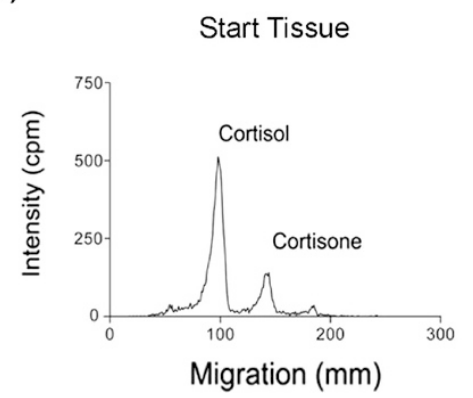

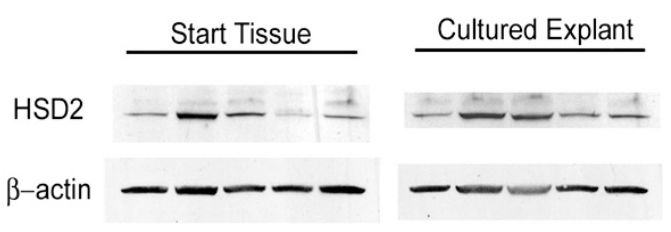

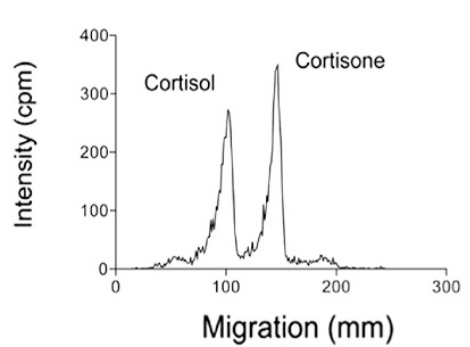

Figure 4. HSD2 mRNA, protein, and enzyme activity in starting fetal lung tissue $v s$ cultured fetal lung explants. (A) Relative amounts of HSD2 mRNA in the starting fetal lung $(n=4)$ and in the cultured fetal lung explants $(n=4)$. (B) HSD2 protein levels in the fetal lung explants before and after $6 \mathrm{~d}$ in culture. Data are from 11 fetal lung samples (starting and cultured fetal lung explant tissues were from same lung). Representative immunoblots for HSD2 and $\beta$-actin are shown on the right. ${ }^{*} p<0.05$ using a paired $t$ test. $(C)$ Summary of HSD2 activity assays in starting human fetal lung tissues and in corresponding cultured explants $(n=5, p=0.14)(a)$; scan of representative plate illustrating the separation of labeled steroid metabolites via thin layer chromatography $(b)$. 

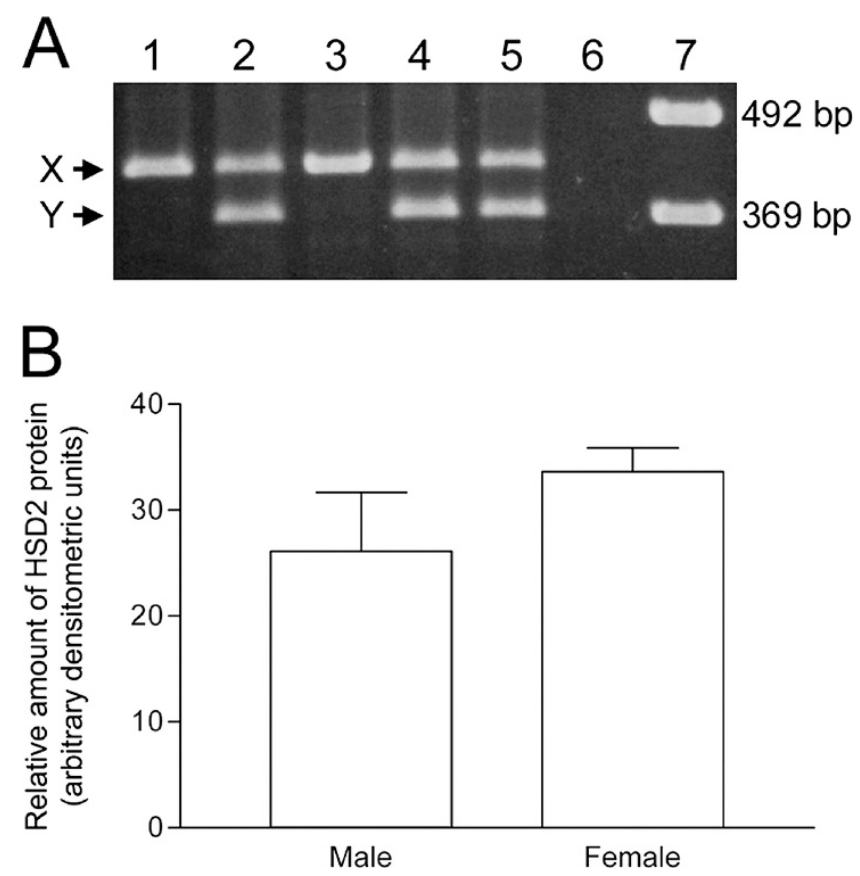

Figure 5. Comparison of the relative amounts of HSD2 protein in male $v s$ female human fetal lung explants. (A) Representative PCR for X and Y chromosome sequences for sex determination of human fetal lung. Female tissues (lanes 1,3) show amplification of only $\mathrm{X}$ chromosome sequences, whereas male tissues show amplification of both $\mathrm{X}$ and $\mathrm{Y}$ chromosome sequences (lanes 2,4,5). (B) Immunoblot analysis for HSD2 protein in male $(n=5)$ and female $(n=3)$ fetal lung tissues.

HSD2 protein levels in either male or female fetal lung explants (Fig. 6B).

\section{DISCUSSION}

The final maturation of the human fetal lung is mediated by a surge in endogenous fetal cortisol levels near term (2). Synthetic GC, e.g. betamethasone and dexamethasone, are routinely administered to pregnant women at risk for preterm delivery to accelerate fetal lung maturation (2). These treatments are effective in reducing the incidence of neonatal lung disease and neonatal mortality (2). GC are also often used in the treatment of asthma and other inflammatory lung diseases (3).
The human fetal lung actively oxidizes the biologically active GC, cortisol, to inactive cortisone, which is indicative of HSD2 activity $(14,15)$. HSD2 gene expression has been detected in human fetal lung via immunohistochemistry, RTPCR, and immunoblot analyses $(12,13)$. In contrast, HSD1 protein is undetectable in human adult and fetal lung tissues $(12,21,22)$. Additionally, no conversion of cortisone to cortisol (indicative of HSD1 activity) has been observed in human fetal lung in vivo (15).

The human fetal lung explant system has been used to study type II alveolar cell differentiation (16), the hormonal regulation of gene expression $(17,23)$, the effects of GC on lung structure (17), as well as the metabolism of GC (24). We observed that HSD2 is expressed at discrete sites in the undifferentiated human fetal lung tissue. Specifically, HSD2 protein was restricted to epithelial cells in the distal regions of the prealveolar ducts where epithelial cell proliferation facilitates the branching morphogenesis required to achieve normal lung structure. The presence of HSD2 in these areas may serve to limit cortisol exposure, which could inhibit proliferation and promote the premature differentiation of these epithelial cells (2).

In contrast, in cultured lung explants containing differentiated alveolar type II cells, HSD2 protein levels appeared to be elevated when compared with levels in the starting fetal lung tissue and the HSD2 protein appeared to be distributed throughout the cytoplasm and in the nucleus. These findings may reflect a nuclear function for HSD2 within differentiated alveolar epithelial cells. We observed an increase in HSD2 protein levels in cultured fetal lung explants. This increase paralleled the differentiation of type II alveolar epithelial cells in the explants (16). HSD2 protein has previously been detected in alveolar type II cells of the human adult lung (25). Similar increases in HSD2 expression have been observed concomitant with the differentiation of human colonic epithelial cells and placental trophoblast cells, suggesting that the expression of this enzyme is influenced by cellular differentiation $(26,27)$.

HSD2 protein in mid-trimester human fetal lung tissue was localized to the apical region of the undifferentiated alveolar epithelial cells. The subcellular localization of this microso-
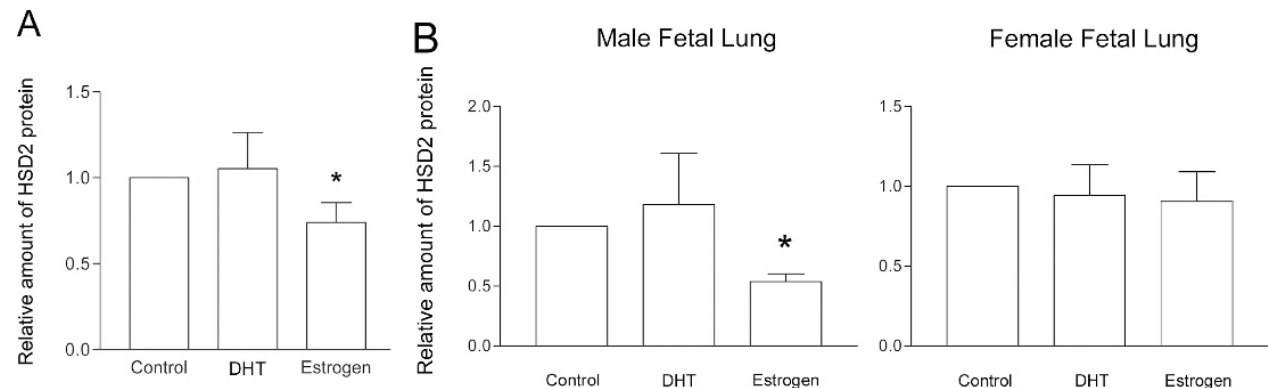

Figure 6. Effects of sex steroids on HSD2 protein levels in cultured fetal lung tissue. Explants were cultured for $6 \mathrm{~d}$ in the presence of either no steroids (control), dihydrotestosterone (DHT), or 17- $\beta$ estradiol (estradiol). (A) Effects of DHT and estradiol on HSD2 protein levels in human fetal lung tissues. 17- $\beta$ estradiol treatment decreased HSD2 protein levels by $26.1 \pm 11 \%\left(n=11,{ }^{*} p<0.05\right.$ using a paired $t$ test $v s$ untreated controls, which were normalized to one). ( $\left.B\right) 17-\beta$ estradiol treatment decreased HSD2 protein levels in male fetal lung explants by $47 \pm 6 \%(n=5, * p<0.05$ using a paired $t$ test $v s$ untreated control tissues, which were made equal to one), but did not affect HSD2 in female fetal lung explants $(n=6)$. DHT exposure did not significantly affect HSD2 protein levels in either male or female fetal lung explants. 
mal enzyme may be related to the location of endoplasmic reticulum in the undifferentiated human lung epithelial cells (28). In contrast, the cultured fetal lung explant tissues expressed HSD2 protein throughout the cytoplasm of the epithelial cells lining the prealveolar ducts, with many cells also exhibiting nuclear localization of HSD2. Nuclear localization of HSD2 protein has been observed in the epithelial cells of other human tissues including the kidney, colon, salivary gland, and endometrium, data suggestive that the metabolism of GC by HSD 2 may also be a nuclear event in these cells (29-31).

We did not observe a statistically significant difference in the levels of HSD2 mRNA and protein in adult versus fetal lung tissues. In addition, undifferentiated, mid-trimester human fetal lung tissues and cultured, differentiated human lung explant tissues expressed similar amounts of HSD2 mRNA. However, the cultured fetal lung explants contained higher levels of HSD2 protein and HSD2 enzymatic activity than the starting fetal lung tissues. Thus, HSD2 protein turnover may be decreased in differentiated type II epithelial cells or the HSD2 gene may be subject to posttranscriptional regulation, as has been reported in other cell types (32). Interestingly, HSD2 activity decreases in the human fetal lung in vivo late in gestation, presumably to allow maximal amounts of biologically active cortisol to promote lung differentiation (11).

There are sex-specific differences in human fetal lung maturation (8). Males have a higher incidence and severity of neonatal lung disease (33). Furthermore, prenatal GC therapy is more effective in preventing respiratory distress syndrome (RDS) in female infants than male infants (34). Androgen exposure has been linked to delayed fetal lung maturation in humans (9). Conversely, it has been reported that $17-\beta$ estradiol treatment accelerates fetal lung maturation, and that estrogen levels are low in human infants with RDS $(10,35)$. Immunoblot analyses of HSD2 protein in mid-gestation male and female fetal lung tissues revealed no significant differences in the baseline levels of HSD2 protein. However, HSD2 levels were significantly decreased by $17-\beta$ estradiol $(50 \%$ decrease) in male fetal lung explants, whereas HSD2 levels in female fetal lung explants were not affected by either $17-\beta$ estradiol or DHT treatment. The concentration of $17-\beta$ estradiol used in this study $(500 \mathrm{ng} / \mathrm{mL}, 1.8 \mu \mathrm{M})$ is similar to the levels of estradiol in fetal plasma (36). The lack of an effect of sex steroids in the female fetal lung explants may be related to the concentration of androgen or estrogen receptors in the fetal lung tissue. The androgen receptor (AR) has been detected in human fetal lung epithelial cells by immunohistochemistry, with lower levels of AR in female than in male fetal lung tissues (37). Human fetal lung tissue specifically binds estrogen, and mRNA transcripts for the $\beta$ - isoform of the estrogen receptor (ER) have been detected in human fetal lung tissues $(38,39)$. ER expression has been reported to be similar in male and female human adult lung (40); however, the relative amount of ER in male versus female human fetal lung has not been established.

As pregnancy progresses, the levels of estrogens in fetal plasma and amniotic fluid rise, with amniotic fluid levels of $17-\beta$ estradiol levels higher in mid-gestation pregnancies with female than with male fetuses $(36,41)$. As a result, female fetuses are exposed to higher levels of estrogen at earlier gestational ages than males. Thus, fetal lung tissues obtained from female fetuses may be less sensitive to exogenous estrogen because there may be fewer unliganded ER that can bind additional estrogen and/or because ER levels can be downregulated by estradiol in human cells (42). Indeed, late gestation male fetal rat lung tissues have been shown to bind significantly more (50\%) $17-\beta$ estradiol than age-matched female fetal rat lung tissues (10).

In summary, we characterized the relative levels of HSD2 mRNA, protein, and enzyme activity in human adult and fetal lung tissues, and in cultured human fetal lung explant tissues undergoing differentiation in vitro. We have examined the relative levels of HSD2 protein in male and female human fetal lung tissues, as well as the regulation of HSD2 by sex steroids. Our data demonstrate that the expression of HSD2 protein in human fetal lung is dynamic and affected by the differentiation state of alveolar epithelial cells. Additionally, we have shown that the expression of HSD2 protein is regulated by $17 \beta$-estradiol in male, but not female, human fetal lung tissues.

\section{REFERENCES}

1. Krozowski Z, Li KX, Koyama K, Smith RE, Obeyesekere VR, Stein-Oakley A, Sasano H, Coulter C, Cole T, Sheppard KE 1999 The type I and type II 11betahydroxysteroid dehydrogenase enzymes. J Steroid Biochem Mol Biol 69:391-401

2. Bolt RJ, van Weissenbruch MM, Lafeber HN, Delemarre-van de Waal HA 2001 Glucocorticoids and lung development in the fetus and preterm infant. Pediatr Pulmonol 32:76-91

3. Pelaia G, Vatrella A, Cuda G, Maselli R, Marsico SA 2003 Molecular mechanisms of corticosteroid actions in chronic inflammatory airway diseases. Life Sci 72:15491561

4. de Fencl M, Tulchinsky D 1975 Total cortisol in amniotic fluid and fetal lung maturation. N Engl J Med 292:133-136

5. NIH Consensus Development Panel on the Effect of Corticosteroids for Fetal Maturation on Perinatal Outcomes 1995 Effect of corticosteroids for fetal maturation on perinatal outcomes. JAMA 273:413-418

6. Seckl JR 2004 Prenatal glucocorticoids and long-term programming. Eur J Endocrinol 151:U49-U62

7. Walfisch A, Hallak M, Mazor M 2001 Multiple courses of antenatal steroids: risks and benefits. Obstet Gynecol 98:491-497

8. Torday JS, Nielsen HC, Fencl Mde M, Avery ME 1981 Sex differences in fetal lung maturation. Am Rev Respir Dis 123:205-208

9. Torday JS 1990 Androgens delay human fetal lung maturation in vitro. Endocrinology 126:3240-3244

10. Adamson IY, Bakowska J, McMillan E, King GM 1990 Accelerated fetal lung maturation by estrogen is associated with an epithelial-fibroblast interaction. In Vitro Cell Dev Biol 26:784-790

11. Murphy BE 1978 Cortisol production and inactivation by the human lung during gestation and infancy. J Clin Endocrinol Metab 47:243-248

12. Garbrecht MR, Schmidt TJ, Krozowski ZS, Snyder JM 2006 11Beta-hydroxysteroid dehydrogenase type 2 and the regulation of surfactant protein A by dexamethasone metabolites. Am J Physiol Endocrinol Metab 290:E653-E660

13. Suzuki T, Sasano H, Suzuki S, Hirasawa G, Takeyama J, Muramatsu Y, Date F, Nagura H, Krozowski ZS 1998 11Beta-hydroxysteroid dehydrogenase type 2 in human lung: possible regulator of mineralocorticoid action. J Clin Endocrinol Metab $83: 4022-4025$

14. Abramovitz M, Branchaud CL, Murphy BE 1982 Cortisol-cortisone interconversion in human fetal lung: contrasting results using explant and monolayer cultures suggest that 11 beta-hydroxysteroid dehydrogenase (EC 1.1.1.146) comprises two enzymes. J Clin Endocrinol Metab 54:563-568

15. Pasqualini JR, Nguyen BL, Uhrich F, Wiqvist N, Diczfalusy E 1970 Cortisol and cortisone metabolism in the human foeto-placental unit at midgestation. J Steroid Biochem 1:209-219

16. Snyder JM, Johnston JM, Mendelson CR 1981 Differentiation of type II cells of human fetal lung in vitro. Cell Tissue Res 220:17-25

17. Odom MJ, Snyder JM, Boggaram V, Mendelson CR 1988 Glucocorticoid regulation of the major surfactant associated protein (SP-A) and its messenger ribonucleic acid and of morphological development of human fetal lung in vitro. Endocrinology 123:1712-1720

18. Klein JM, McCarthy TA, Dagle JM, Snyder JM 2002 Antisense inhibition of surfactant protein A decreases tubular myelin formation in human fetal lung in vitro. Am J Physiol Lung Cell Mol Physiol 282:L386-L393 
19. Krozowski Z, MaGuire JA, Stein-Oakley AN, Dowling J, Smith RE, Andrews RK 1995 Immunohistochemical localization of the 11 beta-hydroxysteroid dehydrogenase type II enzyme in human kidney and placenta. J Clin Endocrinol Metab 80:2203-2209

20. Nakahori Y, Hamano K, Iwaya M, Nakagome Y 1991 Sex identification by polymerase chain reaction using X-Y homologous primer. Am J Med Genet 39:472-473

21. Suzuki S, Koyama K, Darnel A, Ishibashi H, Kobayashi S, Kubo H, Suzuki T, Sasano H, Krozowski ZS 2003 Dexamethasone upregulates 11beta-hydroxysteroid dehydrogenase type 2 in BEAS-2B cells. Am J Respir Crit Care Med 167:12441249

22. Suzuki S, Tsubochi H, Ishibashi H, Suzuki T, Kondo T, Sasano H 2003 Increased expression of 11 beta-hydroxysteroid dehydrogenase type 2 in the lungs of patients with acute respiratory distress syndrome. Pathol Int 53:751-756

23. Dekowski SA, Snyder JM 1992 Insulin regulation of messenger ribonucleic acid for the surfactant-associated proteins in human fetal lung in vitro. Endocrinology 131:669-676

24. Abramovitz M, Carriero R, Murphy BE 1984 Investigation of factors influencing 11 beta-hydroxysteroid dehydrogenase (EC 1.1.1.146) activity in midgestational human fetal lung monolayer and explant cultures. J Steroid Biochem 21:677-683

25. Hirasawa G, Sasano H, Takahashi K, Fukushima K, Suzuki T, Hiwatashi N, Toyota T, Krozowski ZS, Nagura H 1997 Colocalization of 11 beta-hydroxysteroid dehydrogenase type II and mineralocorticoid receptor in human epithelia. J Clin Endocrinol Metab 82:3859-3863

26. Takahashi K, Sasano H, Fukushima K, Hirasawa G, Miura H, Sasaki I, Matsuno S, Krozowski ZS, Nagura H 199811 beta-hydroxysteroid dehydrogenase type II in human colon: a new marker of fetal development and differentiation in neoplasms. Anticancer Res 18:3381-3388

27. Hardy DB, Yang K 2002 The expression of 11 beta-hydroxysteroid dehydrogenase type 2 is induced during trophoblast differentiation: effects of hypoxia. J Clin Endocrinol Metab 87:3696-3701

28. Mallampalli RK, Acarregui MJ, Snyder JM 1997 Differentiation of the alveolar epithelium in the fetal lung. In: McDonald JA (ed) Lung Growth and Development. Marcel Dekker, Inc., New York, New York, pp 119-162

29. Smith RE, Salamonsen LA, Komesaroff PA, Li KX, Myles KM, Lawrence M, Krozowski Z 199711 beta-Hydroxysteroid dehydrogenase type II in the human endometrium: localization and activity during the menstrual cycle. J Clin Endocrinol Metab 82:4252-4257

30. Shimojo M, Ricketts ML, Petrelli MD, Moradi P, Johnson GD, Bradwell AR, Hewison M, Howie AJ, Stewart PM 1997 Immunodetection of 11 beta- hydroxysteroid dehydrogenase type 2 in human mineralocorticoid target tissues: evidence for nuclear localization. Endocrinology 138:1305-1311

31. Petrelli MD, Lim-Tio SS, Condon J, Hewison M, Stewart PM 1997 Differential expression of nuclear 11 beta-hydroxysteroid dehydrogenase type 2 in mineralocorticoid receptor positive and negative tissues. Endocrinology 138:3077-3080

32. Lanz B, Kadereit B, Ernst S, Shojaati K, Causevic M, Frey BM, Frey FJ, Mohaupt MG 2003 Angiotensin II regulates 11beta-hydroxysteroid dehydrogenase type 2 via AT2 receptors. Kidney Int 64:970-977

33. Stevenson DK, Verter J, Fanaroff AA, Oh W, Ehrenkranz RA, Shankaran S, Donovan EF, Wright LL, Lemons JA, Tyson JE, Korones SB, Bauer CR, Stoll BJ, Papile LA 2000 Sex differences in outcomes of very low birthweight infants: the newborn male disadvantage. Arch Dis Child Fetal Neonatal Ed 83:F182-F185

34. Ballard PL, Ballard RA, Granberg JP, Sniderman S, Gluckman PD, Kaplan SL, Grumbach MM 1980 Fetal sex and prenatal betamethasone therapy. J Pediatr 97:451-454

35. Dickey RP, Robertson AF 1969 Newborn estrogen excretion. Its relationship to sex, birth weight, maternal complications, and idiopathic respiratory distress syndrome. Am J Obstet Gynecol 104:551-555

36. Shutt DA, Smith ID, Shearman RP 1974 Oestrone, oestradiol-17beta and oestriol levels in human foetal plasma during gestation and at term. J Endocrinol $60: 333-341$

37. Kimura Y, Suzuki T, Kaneko C, Darnel AD, Akahira J, Ebina M, Nukiwa T, Sasano H 2003 Expression of androgen receptor and 5alpha-reductase types 1 and 2 in early gestation fetal lung: a possible correlation with branching morphogenesis. Clin Sci (Lond) 105:709-713

38. Mendelson CR, MacDonald PC, Johnston JM 1980 Estrogen binding in human fetal lung tissue cytosol. Endocrinology 106:368-374

39. Brandenberger AW, Tee MK, Lee JY, Chao V, Jaffe RB 1997 Tissue distribution of estrogen receptors alpha (ER-alpha) and beta (ER-beta) mRNA in the midgestational human fetus. J Clin Endocrinol Metab 82:3509-3512

40. Mollerup S, Jorgensen K, Berge G, Haugen A 2002 Expression of estrogen receptors alpha and beta in human lung tissue and cell lines. Lung Cancer 37:153-159

41. Robinson JD, Judd HL, Young PE, Jones OW, Yen SS 1977 Amniotic fluid androgens and estrogens in midgestation. J Clin Endocrinol Metab 45:755-761

42. Saceda M, Lippman ME, Chambon P, Lindsey RL, Ponglikitmongkol M, Puente M, Martin MB 1988 Regulation of the estrogen receptor in MCF-7 cells by estradiol. Mol Endocrinol 2:1157-1162 